\title{
Acetylcholinesterase Expression in Muscle Is Specifically Controlled by a Promoter-Selective Enhancesome in the First Intron
}

\author{
Shelley Camp, Antonella De Jaco, Limin Zhang, Michael Marquez, Brian De La Torre, and Palmer Taylor \\ Department of Pharmacology, Skaggs School of Pharmacy and Pharmaceutical Sciences, University of California, San Diego, La Jolla, California 92093-0650
}

\begin{abstract}
Mammalian acetylcholinesterase $(A C h E)$ gene expression is exquisitely regulated in target tissues and cells during differentiation. An intron located between the first and second exons governs a $\sim 100$-fold increase in AChE expression during myoblast to myotube differentiation in $\mathrm{C} 2 \mathrm{C} 12$ cells. Regulation is confined to $255 \mathrm{bp}$ of evolutionarily conserved sequence containing functional transcription factor consensus motifs that indirectly interact with the endogenous promoter. To examine control in vivo, this region was deleted by homologous recombination. The knock-out mouse is virtually devoid of AChE activity and its encoding mRNA in skeletal muscle, yet activities in brain and spinal cord innervating skeletal muscle are unaltered. The transcription factors MyoD and myocyte enhancer factor-2 appear to be responsible for muscle regulation. Selective control of AChE expression by this region is also found in hematopoietic lineages. Expression patterns in muscle and CNS neurons establish that virtually all AChE activity at the mammalian neuromuscular junction arises from skeletal muscle rather than from biosynthesis in the motoneuron cell body and axoplasmic transport.
\end{abstract}

Key words: enhancesome; myogenesis; knock-out mouse; acetylcholinesterase; differentiation; muscle

\section{Introduction}

Characterization of the mammalian acetylcholinesterase $(A C h E)$ gene, initially from isolated cDNAs (Rachinsky et al., 1990; Soreq and Zakut, 1990) and then from genomic clones (Li et al., 1991), reveals a compact gene confined to $7.4 \mathrm{~kb}$ from the primary transcription start site to the more distal of two polyadenylation signals. Three short introns are found in the invariantly spliced sequence between exons 1 and 4, and two alternative splice acceptors exist near the 3 '-end of the gene, producing AChE with three distinct $\mathrm{C}$-terminal sequences. Divergence in the very C-terminal sequences of AChE governs the oligomerization state of the enzyme and its membrane-tethering properties but does not directly affect the catalytic parameters (Massoulie, 2002; Radic and Taylor, 2006). In addition, there have been several reports describing alternative promoter usage and splicing at the 5 '-end of the gene (Atanasova et al., 1999; Meshorer et al., 2004).

Despite the inherent complexity of gene expression arising from alternative splicing, the limited nucleotide span of the $A C h E$

Received 0ct. 9, 2007; revised Jan. 9, 2008; accepted Jan. 17, 2008.

This work was supported by grants from the National Institutes of Health (R37-GM18360-33), the National Institute of Environmental Health Sciences (P42ES010337) to P.T., and a Rotary Foundation Ambassadorial Scholar Fellowship to A.D.J. We are most grateful for the work of the Transgenic Mouse and Gene Targeting Core at the University of California, San Diego, especially Ella Kothari, who maintained the stem cells, performed stem cell transfections, and performed the blastocyst injections. We thank Dr. J. Marth, who provided the vector pFlox (Chui et al., 1997), and Dr. A. Wynshaw-Boris and Patricia LaPorte, who provided the Ella-cre transgenic mice (Xu et al., 2001).

Correspondence should be addressed to Palmer Taylor, Department of Pharmacology, Skaggs School of Pharmacy and Pharmaceutical Sciences, University of California, San Diego, La Jolla, CA 92093-0650. E-mail: pwtaylor@ucsd.edu.

DOI:10.1523/JNEUROSCI.4600-07.2008

Copyright $\odot 2008$ Society for Neuroscience $\quad$ 0270-6474/08/282459-12\$15.00/0 gene with its short introns enables one to examine expression after transfection of an intact gene rather than monitoring expression of gene fragments attached to reporter genes.

AChE expression in excitable cells, such as skeletal muscle, is characterized by greatly enhanced expression after differentiation (Inestrosa et al., 1983). The enzyme is virtually absent in myoblasts or neuroblasts; differentiation into myotubes and neurons (Jones-Villeneuve et al., 1983) results in large increases in AChE mRNA and protein levels.

A series of studies using run-on transcription and reporter gene expression has demonstrated rather modest transcriptional control of mammalian AChE gene expression (Fuentes and Taylor, 1993; Mutero et al., 1995; Angus et al., 2001). Studies in cultured muscle cells reveal evidence for mRNA stabilization (Fuentes and Taylor, 1993; Deschenes-Furry et al., 2005), but stabilization of mRNA is not sufficient to explain the large increases in activity or mRNA levels associated with myoblast to myotube differentiation. Studies using inhibitors of RNA polymerase stabilize a labile RNA in myoblasts and provide evidence for superinduction of the mRNA (Fuentes and Taylor, 1993). Hence, labile proteins may control AChE mRNA stability, but here, again, differences in the rates of mRNA degradation do not appear sufficient to account for the marked increases in mRNA levels associated with myoblast to myotube conversion.

We have taken advantage of the compact nature of the AChE gene permitting us to transfect it in its entirety and compare the expression from transfected and endogenous genes in differentiating muscle cells. Through successive and reiterative gene deletions, we delineated a critical region in the first intron of the gene, between exons 1 and 2, that exerts dominant regulatory control of gene expression during the relatively rapid myoblast to myo- 
tube differentiation in culture. The identified region has multiple functional consensus sites for gene regulation (Angus et al., 2001) that are conserved in mammalian species. It functions only with its endogenous AChE promoter in concert with other areas of the gene, suggesting enhancesome-like behavior (Merika and Thanos, 2001; Arnosti and Kulkarni, 2005).

To examine whether the control of $A C h E$ gene expression is characteristic of particular tissues, and we deleted this intronic region by homologous recombination, allowing the altered gene to be expressed in the developing mouse. Remarkably, deletion of this intronic region in knock-out animals ablates AChE mRNA synthesis and protein expression in skeletal muscle, as indicated in cell culture expression, yet surprisingly, and in contrast to deletion of alternatively spliced exonic regions, brain and spinal cord expression patterns are not altered. Moreover, distinguishing differences in expression controlled by these intronic elements are found in two types of hematopoietic cell lineages; erythroid cells show normal AChE, whereas expression in the platelet arising from a megakarocyte lineage is ablated.

\section{Materials and Methods}

Unless otherwise indicated, reagents were obtained from Sigma-Aldrich (St. Louis, MO). DNA restriction and modifying enzymes were obtained from Ambion (Austin, TX), New England Biolabs (Beverly, MA), and Invitrogen (Carlsbad, CA). Chick embryo extract came from Accurate Chemical and Scientific Corporation (Westbury, NY). Oligonucleotides were synthesized by Genosys Biotechnologies (The Woodlands, TX). Tissue culture supplies were obtained from Invitrogen. Nuclear extracts from $\mathrm{C} 2 \mathrm{C} 12$ cells were generated with Active Motif (Carlsbad, CA) materials. Electrophoretic mobility shift assay (EMSA) buffer was obtained from Novagen (EMD Chemicals, San Diego, CA). Antibodies from Santa Cruz Biotechnology (Santa Cruz, CA) included the following: myocyte enhancer factor-2 (MEF2) Ab1, s.c.-313x; MEF2 Ab2, s.c.-10794x; MEF2 Ab3, s.c.-17785x; MyoD, s.c.-32758x; muscle regulatory factor-4 (MRF4), s.c.-301x; serum responsive factor (SRF) Ab1, s.c.-335x; and SRF Ab2, s.c.-13029x. ${ }^{32} \mathrm{P}$ nucleotides were obtained from PerkinElmer (Waltham, MA). RNA was reverse-transcribed into single-stranded cDNA using the Superscript First-Strand System from Invitrogen.

Location of sequences in the AChE gene. Numbering used to locate sequences in the $A C h E$ gene is found in GenBank accession number AF312033 (Wilson et al., 2001). As a point of reference, AChE exon 1 begins at $\sim 7510$ (multiple cap region) and ends at 7607. Exon 2, 925610345; exon 3, 10723-11207; exon 4, 12434-12603; retained intron ORF stop at 12693; alternative exon 5 ORF, 12720-TAA stop at 12846; alternative exon 6 ORF, 13384-TGA stop at 13503 . The first and second polyadenylation signals are at 13711 and 14909.

AChE gene plasmids. All plasmid constructs used in $\mathrm{C} 2 \mathrm{C} 12$ cell transfections are based on the $8.3 \mathrm{~kb}$ murine genomic HindIII fragment isolated from a Lambda Fix library (Li et al., 1991) and inserted into the unique HindIII restriction site in the cloning vector pBluescript SK $2+$ (Stratagene, La Jolla, CA.). Intron deletions were made by splicing genomic and cDNA (Rachinsky et al., 1990) using unique restriction sites, multifragment ligations, and multistep constructions. Site-directed mutagenesis (Stratagene QuikChange site-directed method), two-step PCR (Malcolm and Wang, 1999), and double-stranded synthetic oligonucleotides were used to construct mutations and deletions.

Cell culture. The mouse muscle cell line, $\mathrm{C} 2 \mathrm{C} 12$, was obtained from American Type Culture Collection (Manassas, VA). Cells were maintained in a humidified atmosphere at $37^{\circ} \mathrm{C}, 10 \% \mathrm{CO}_{2}$ in growth media that consisted of $20 \%$ fetal bovine serum, and $0.5 \%$ chick embryo extract in DMEM. Cells for each experiment were passed from frozen stocks no more than four times before use. Fusion media, to affect differentiation of myoblasts to myotubes, consisted of $2 \%$ horse serum in DMEM.

Cell transfections. C2C12 cells were plated $\sim 15 \mathrm{~h}$ before transfection at densities to achieve $\sim 80 \%$ confluence at transfection. DNA for transfections was purified by polyethylene glycol precipitation and sedimentation in a $\mathrm{CsCl}$ gradient. The plasmid of interest was cotransfected with the lipid reagent LipofectAMINE PLUS (Invitrogen) at a ratio of 4:1 with cytomegalovirus (CMV) $\beta$-galactosidase to correct for transfection efficiency. Transfected cells were rinsed with PBS and lifted with trypsin (ATV solution; Invitrogen). Transfected cells were replated at different densities to allow direct comparisons between growing and differentiating cells. After $6 \mathrm{~h}$ of recovery in growth media, cells were cultured in either growth or differentiation conditions. Thereafter, media was changed daily.

Cell harvest and analysis of enzyme activity. Cells were rinsed and then scraped from plates in PBS. Cell-associated AChE was extracted from the transfected C2C12 cells in $0.01 \mathrm{M} \mathrm{NaPO}_{4}$ buffer, pH 7.5, containing $1 \mathrm{M}$ $\mathrm{NaCl}, 1 \%$ Triton X-100, 0.01 м EGTA plus a mixture of protease inhibitors: $5 \mu \mathrm{g} / \mathrm{ml}$ each of pepstatin A, leupeptin, and aprotinin, $10 \mu \mathrm{g} / \mathrm{ml}$ bacitracin, and $0.01 \mathrm{~mm}$ benzamidine (Duval et al., 1992). Cells were sonicated, held on ice for $10 \mathrm{~min}$, and then spun at 12,000 $\times \mathrm{g}$ for $10 \mathrm{~min}$. Supernatants were analyzed for AChE activity (Ellman et al., 1961) in 0.1

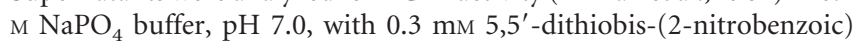
acid, $0.5 \mathrm{~mm}$ acetylthiocholine iodide at room temperature. $\beta$-Galactosidase activity in the supernatant was determined as the rate of color development at $412 \mathrm{~nm}$ in $0.1 \mathrm{M} \mathrm{NaPO}_{4}$ buffer, pH 7.3, $1 \mathrm{~mm}$ $\mathrm{MgCl}_{2}, 50 \mathrm{~mm} \beta$-mercaptoethanol, and $0.8 \mathrm{mg} / \mathrm{ml} o$-nitrophenyl- $\beta$-Dgalactopyranoside, at $25^{\circ} \mathrm{C}$.

Normalization of transfections of different gene constructs. Because C2C12 myoblasts and myotubes show very different transfection efficiencies, cells were transfected at a common stage of growth and then separated to be differentiated or maintained in a dividing state. Endogenous cellular AChE expression was assessed by parallel transfections of empty vector; AChE was normalized to total protein. AChE expression during proliferation or differentiation was corrected for transfection efficiency using $\beta$-galactosidase activity from cells harvested $24 \mathrm{~h}$ posttransfection. Altered gene activity is reported as a fold increase or decrease relative to mouse $A C h E$ gene (MAG).

RNase protection. An AChE gene subclone in pBluescript $\mathrm{SK}+$ (base pair 9114-9503), encompassing the junction of intron 1 and exon 2, was used as a template for in vitro transcription of an RNA protection probe. Protection experiments were performed essentially as described by Gilman (2001) using $10 \mu \mathrm{g} / \mathrm{ml}$ RNase A and $150 \mathrm{U} / \mathrm{ml}$ RNase T1. To detect endogenous message, $50 \mu \mathrm{g}$ of total RNA was used, whereas $10 \mu \mathrm{g}$ of RNA revealed the transfected message.

Sequence analysis. The mouse genomic sequence from 8184 to 8456 (GenBank accession number 312033) in AChE intron 1 was used in a BLAT search of the UCSC genome browser database (http://genome. ucsc.edu) (Kent, 2002; Karolchik et al., 2003) to identify corresponding sequences in human, rhesus monkey, cow, and dog genomes. The rat sequence is from GenBank accession number AF134349 (Chan et al., 1999). Multiple sequence alignment was compiled with the program CLUSTALW at GenomeNet (http://www.genome.ad.jp) and formatted using BOXSHADE and TEXSHADE.

Knock-out mice. All experiments were performed in accordance with the University of California at San Diego's Institutional Animal Care and Use Committee (National Institutes of Health assurance number A3033-1; United States Department of Agriculture Animal Research Facility registration number 93-R-0437).

AChE knock-out nomenclature. Floxing of AChE intron regulatory region knock-out mouse (acheilrr) denotes that base pair 8179-8434 in intron 1 were flanked by loxP sites producing the acheil $\mathrm{rr}^{\text {FLOXED }}$ mouse. The floxed intron 1 regulatory region was then deleted by mating to an Ella-Cre transgenic mouse. Resulting pups with the 255 bp region deleted were mated producing an independent colony, acheilrr. acheilrr ${ }^{\text {FLOXED }}(-/-)$ and acheilrr $(-/-)$ homozygous mice are compared independently with their wild-type and heterozygous littermates. For the exon 6 deleted knock-out mouse (acheE6), base pair 1330713562 were deleted. This sequence includes the exon 6 splice acceptor as well as the entire ORF of exon 6 . The inserted loxP flanked neomycin cassette was then deleted through the expression of Cre-recombinase (Fig. S5, available at www.jneurosci.org as supplemental material).

Knock-out mouse constructs. Basic recombinant DNA techniques were used in construction of plasmids for gene targeting. Constructs and screening for the deletion of the intron 1 regulatory region and exon 6 are 
described in Figures S4 and S5 (available at www.jneurosci.org as supplemental material), respectively. Most importantly, all mouse genomic DNA was from the strain 129 SvJ to ensure identity with the transfected stem cells. DNA used in constructs either came from a $129 \mathrm{SvJ}$ library (clone address 341/C04, BAC Mouse ES Rel II; Incyte Genomics, Palo Alto, CA) or was amplified by PCR from 129SvJ stem cell genomic DNA. The cassette used in the intron regulatory region deletion construct (loxP/neomycin, thymidine kinase/loxP) came from a pFlox vector provided by Dr. J. Marth (University of California, San Diego, La Jolla, CA) (Chui et al., 1997). The selection cassette (loxP/neomycin/loxP) used in the deletion of exon 6 came from Dr. G. Bucht (Swedish Defence Research Agency, Umeå, Sweden) (Camp et al., 2005). In all constructs, pBluescript (Stratagene) served as the vector backbone for bacterial amplification.

Principles of gene targeting. Concepts used in the generation of the knock-out mice are described by Joyner (2000).

Tissue AChE activity. Tissue activity is expressed as units of AChE activity per gram of tissue. AChE was extracted by powdering tissue in a mortar and pestle at liquid nitrogen temperatures and then homogenizing the powder, on ice, in $0.01 \mathrm{M} \mathrm{NaPO}_{4}$ buffer, $\mathrm{pH} 7.0$, with $1.0 \mathrm{M} \mathrm{NaCl}$, $0.01 \mathrm{~m}$ EGTA, and $0.5 \%$ Tween 20 , supplemented with the same quintet of protease inhibitors used in the $\mathrm{C} 2 \mathrm{C} 12$ assays. Muscle and spinal cord were homogenized in $25 \mathrm{vol}$ of buffer and the brain in $10 \mathrm{vol}$. The supernatants of $12,000 \times g 10$ min centrifugations, were assayed for activity as described above. Ethopropazine $(10 \mu \mathrm{M})$ was used to inhibit butyrylcholinesterase (BuChE).

Red cell ghost AChE activity. Red cell ghosts were prepared essentially as in the study by Dodge et al. (1963). Blood drawn by cardiac puncture into sodium citrate was initially spun at $2400 \times g$ for $5 \mathrm{~min}$ at $4^{\circ} \mathrm{C}$. Washed red cell ghosts were then sonicated. Activity is reported as units of AChE per milliliter of blood drawn.

Platelet AChE activity. Platelets, virtually free of red and white cells, were collected from citrated blood on OptiPrep gradients (Axis-Shield, Oslo, Norway). Iodixanol-NaCl/HEPES gradients were prepared by dilution of the OptiPrep stock to a density of $1.063 \mathrm{~g} / \mathrm{ml}$. Blood was applied to the diluted gradient material and spun at $600 \mathrm{rpm}$ for $15 \mathrm{~min}$ at $22^{\circ} \mathrm{C}$ with no brake. Platelet rich plasma (PRP) was collected and spun at $450 \times g$ for $10 \mathrm{~min}$ to collect platelets. Platelets were washed, maintained, and assayed in modified HEPES/Tyrode's buffer (10 mM HEPES, $137 \mathrm{~mm}$ $\mathrm{NaCl}, 2.8 \mathrm{~mm} \mathrm{KCl}, 1 \mathrm{~mm} \mathrm{MgCl} 2,12 \mathrm{~mm} \mathrm{NaHCO}_{3}, 0.4 \mathrm{~mm} \mathrm{Na}_{2} \mathrm{HPO}_{4}$, $0.1 \%$ BSA, $5.5 \mathrm{~mm}$ glucose, $\mathrm{pH}$ 7.4) to minimize platelet activation and assess surface AChE only. Activities in this modified buffer were corrected for reduced catalytic efficiency.

Karnovsky-Roots staining of mouse diaphragms. Staining according to Karnovsky and Roots methods as modified by Feng and Carlson (1994) was used to evaluate AChE activity in diaphragm muscle. Briefly, blood was withdrawn from an anesthetized mouse by cardiac puncture. The diaphragm was dissected and rinsed free of blood in normal saline. $\mathrm{BuChE}$ in the tissue was inhibited by incubating for $10 \mathrm{~min}$ with $100 \mu \mathrm{M}$ Iso-OMPA (tetraisopropylpyrophosphoramide). Diaphragms were fixed in $1 \%$ paraformaldehyde for $10 \mathrm{~min}$ on ice and then rinsed with normal saline. Tissue was stained for AChE activity for $1.5 \mathrm{~h}$ at $25^{\circ} \mathrm{C}$ in 1.7 $\mathrm{mm}$ acetylthiocholine iodide in $185 \mathrm{~mm}$ sucrose, $32.5 \mathrm{~mm}$ sodium maleate, $15 \mathrm{~mm}$ sodium citrate, $0.5 \mathrm{~mm}$ potassium ferricyanide, and $3 \mathrm{~mm}$ cupric sulfate, $\mathrm{pH}$ 5.0.

Real-time reverse transcription-PCR. Tissues were disrupted with mortar and pestle and then homogenized by sonication. After digesting with Proteinase K, total cellular RNA was purified with an RNeasy Midi kit (Qiagen, Leusden, The Netherlands). DNase I turbo treatment (Ambion) was used to avoid genomic DNA contamination. RNA was reversetranscribed into single-stranded cDNA using the Superscript FirstStrand System (Invitrogen). The resulting cDNA was subjected to realtime reverse transcription (RT)-PCR using SYBR Green and amplified for 40 cycles with $15 \mathrm{~s}$ at $95^{\circ} \mathrm{C}$ and $60 \mathrm{~s}$ at $60^{\circ} \mathrm{C}$ in the $\mathrm{ABI}$ Prism 7700 Sequence Detector System (Applied Biosystems, Foster City, CA). After amplification, the sequence was confirmed by melting curve analysis. All assays were run in duplicate, and the mean was analyzed from three to six mice. The relative abundance of mRNAs was normalized to cyclophilin mRNA for each sample set. Differences between the wild-type and knock-out animal strains were calculated by the comparative Ct method (Livak and Schmittgen, 2001). The AChE (exon 2-exon 3) primer set used to amplify AChE message is described in the supplemental material (available at www.jneurosci.org).

EMSA. Nuclear extracts for EMSAs were prepared from C2C12 cells, both proliferating myoblasts and $4 \mathrm{~d}$ differentiated myotubes, using a nuclear extract kit from Active Motif. Nuclear extracts were analyzed for protein by BCA assay (Pierce, Rockford, IL), aliquoted, and stored at $-80^{\circ} \mathrm{C}$. EMSAs were run as described by Buratowski and Chodosh (2001). Double-stranded oligonucleotide probes (see Fig. 3) (see supplemental data for specific sequences, available at www.jneurosci.org as supplemental material) were made by annealing sense and antisense oligos and then labeling them with the appropriate ${ }^{32} \mathrm{P}$ dNTP using the Klenow fragment of DNA polymerase I. Free label was removed using the Qiagen Qiaquick Nucleotide removal kit. EMSA binding reactions, using the Novagen EMSA accessory kit, were run at $25^{\circ} \mathrm{C}$ in a $20 \mu \mathrm{l}$ volume containing $100 \mathrm{~mm} \mathrm{KCl,} 20 \mathrm{~mm}$ HEPES, pH 8, 0.1 mм EDTA, 20\% glycerol, $0.5 \mathrm{~mm}$ DTT, $500 \mathrm{ng}$ sonicated herring sperm DNA and $0.01 \mathrm{U}$ Poly $(\mathrm{dI} \cdot \mathrm{dC}) \cdot$ Poly $(\mathrm{dI} \cdot \mathrm{dC}), 10 \mu \mathrm{g}$ of nuclear extract, and $\sim 100 \mathrm{fmol}$ of labeled probe. Unlabeled oligonucleotides in a 50 -fold molar excess were included in competition reactions. Nuclear extract and labeled probe were incubated for $30 \mathrm{~min}$. Competing unlabeled oligonucleotides were incubated with the nuclear extract for $20 \mathrm{~min}$ before adding the labeled probe. Antibodies ( $1 \mu \mathrm{l}$ of TransCruz reagent antibody from Santa Cruz Biotechnology supplied at $2 \mu \mathrm{g} / \mu \mathrm{l}$ ) were added to the [probe + extract reaction] and incubated for an additional $30 \mathrm{~min}$. Binding mixtures were then run on 5\% (37.5 Acrylamide:1 Bis-acrylamide) gels in $1 \times$ TBE $(90$ mu Tris-borate and 2 mм EDTA, $\mathrm{pH} 8.3$ ). Gels were prerun for $1 \mathrm{~h}$ at 200 $\mathrm{V}$, samples were loaded, and the gels were run at $200 \mathrm{~V}$ for $2.5 \mathrm{~h}$.

\section{Results}

Enhanced expression of endogenous and transfected genes in differentiating C2C12 muscle cells

We compared expression of the endogenous $A C h E$ gene in C2C12 muscle cells with expression of a transfected genomic sequence, MAG, an $8.3 \mathrm{~kb}$ HindIII genomic fragment containing the entire $A C h E$ gene, including 390 bp $5^{\prime}$-untranslated region (UTR), exons 1-6 with intervening introns, and $1927 \mathrm{bp}$ of $3^{\prime}$ sequence including two alternative polyadenylation signals. As seen previously (Inestrosa et al., 1983; Fuentes and Taylor, 1993), endogenous AChE increases over $4 \mathrm{~d}$ of differentiation with the gene product accumulating $>10$-fold. The transfected gene shows expression increases in myotubes of up to 100-fold relative to that in the myoblast in a $4 \mathrm{~d}$ period. This pattern reveals not only similar regulation after differentiation, but that $\mathrm{C} 2 \mathrm{C} 12$ cells are not limited in their capacities to express the introduced gene (Fig. 1 $A, B$ ). Parallel increases in endogenous and transfected mRNA encoding AChE were also evident (Fig. 1C,D).

We then examined whether distinct noncoding or intronic regions of the endogenous gene control expression in C2C12 cells by individually deleting the intronic components and the $3^{\prime}$ untranslated regions of the $8.3 \mathrm{~kb}$ genomic fragment (Fig. S1, available at www.jneurosci.org as supplemental material). Although we observed moderate alterations in expression relative to the intact gene, what is most dramatic and distinctive is the virtual loss of activity seen when intron 1 is deleted.

Deconstruction of intron 1 (Fig. $2 \mathrm{~A}$ ) reveals that deletion constructs D, F, and $\mathrm{K}$ showed as much as a fivefold enhancement of activity; deletions of other regions inhibit expression of the gene. Hence, multiple regions of this $1.65 \mathrm{~kb}$ intron coordinate expression in a positive or negative manner. Examining deletions that result in loss of activity clearly reveals that a segment of $255 \mathrm{bp}$ is required to achieve full expression of the full-length gene or enhanced activity from accompanying surrounding deletions (Fig. $2 A$ ). If this region is inverted, the expression level is essentially maintained (Fig. S2 A, available at www.jneurosci.org as supple- 

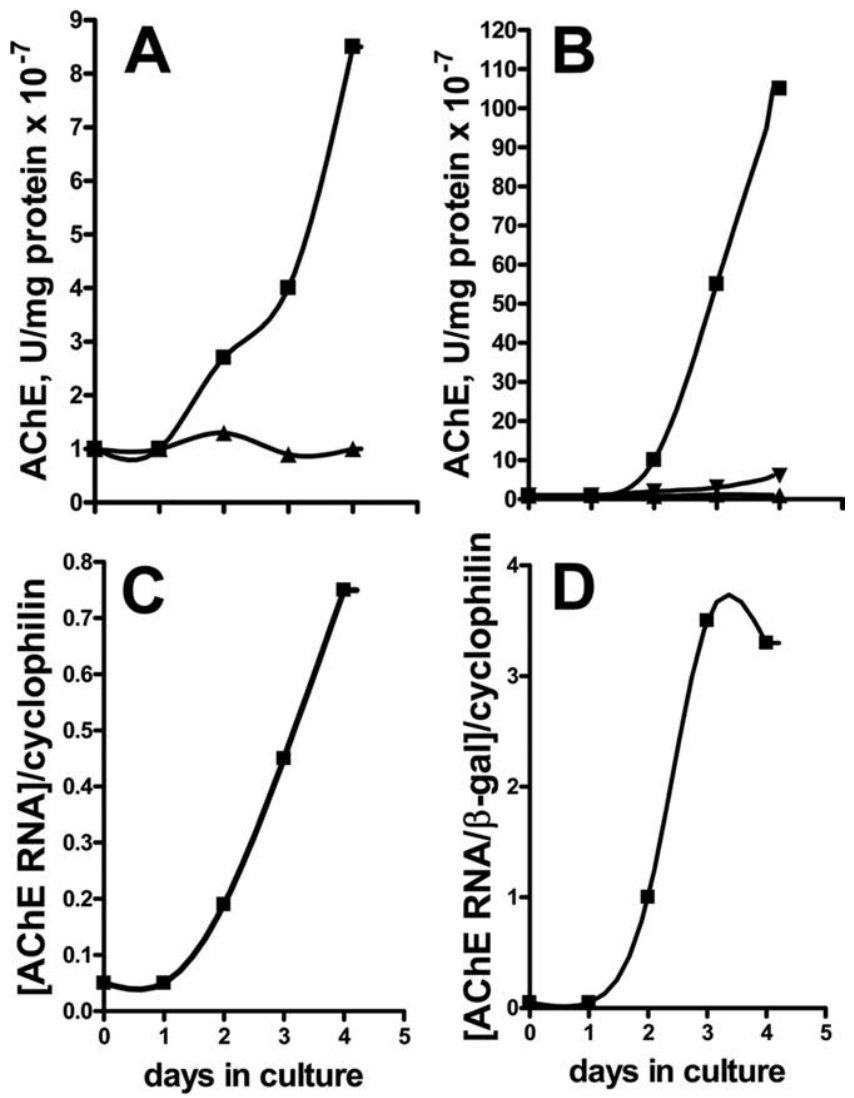

Figure 1. AChE activity and mRNA expression in C2C12 muscle cells. Myoblasts are cells growing in $20 \%$ fetal bovine serum, and myotubes are cells growing in $2 \%$ horse serum. Cells are transfected as myoblasts. $\boldsymbol{A}$, Endogenous AChE activity in myotubes ( $\square$ ) and myoblasts ( $\mathbf{A}$ ). $\boldsymbol{B}, A C h E$ activity in cells transfected with the $A C h E$ gene construct MAG. Myotubes transfected with MAG, $\square$; myotubes transfected with vector, $\nabla$; myoblasts transfected with MAG, $\mathbf{A}$. C, D, Analysis of AChE mRNA levels by RNase protection in myotubes and myoblasts. C, Protection of endogenous RNA, AChE message is normalized to endogenous cyclophilin. $\boldsymbol{D}$, Protection of transfected RNA normalized to a cotransfected $\beta$-galactosidase construct and then to endogenous cyclophilin.

mental material). Control of expression appears to be position dependent, because the intronic sequence does not influence activity when placed between exons 3 and 4 or after exon 6 in the untranslated region (Fig. S2 B, available at www.jneurosci.org as supplemental material).

Importantly, this region only appears to enhance activity associated with the endogenous $A C h E$ promoter and not other exogenous viral promoters (Fig. $2 B$ ). In short, to show enhanced expression associated with muscle differentiation, the enhancer region must be positioned within a defined region. Neither the promoter nor enhancer confer high expression without the partnering sequence. Sequence in this localized intronic region is also well conserved among mammalian species (Fig. 3). An expanded comparison of human and mouse $A C h E$ genes that includes exon 1, intron 1, and part of exon 2 (Fig. S3, available at www. jneurosci.org as supplemental material) further emphasizes this localized identity.

Tissue-specific expression of gene-deleted cells

Although differentiation-mediated expression patterns in cell culture point to a discrete regulatory region in the gene, deletion of the region in the intact animal should provide the best evidence for tissue-specific regulation. To this end, a knock-out mouse strain was generated devoid of the 255 bp region known to regu- late gene expression in vitro (Fig. $2 \mathrm{~A}$ ). The sequence between residues 8181 and 8436 in GenBank accession number AF312033 (Wilson et al., 2001) was altered by homologous recombination to produce a mouse with a floxed intron, acheil $\mathrm{rr}^{\text {FLOXED }}$ (see Materials and Methods) (Fig. S4, available at www.jneurosci.org as supplemental material). Breeding a floxed animal to a mouse expressing the Cre-recombinase transgene (Xu et al., 2001) deleted the conserved regulatory region, producing the knock-out mouse acheilrr.

Insertion of loxP sites into the genome results in no alteration of activity in the CNS or muscle (Table 1, acheil $\mathrm{rr}^{\text {FLOXED }}$ ), but deletion of the intron 1 region surprisingly yields a mouse, acheilrr, with normal brain and spinal cord AChE but with virtually no AChE activity in skeletal muscle (Table 1). The dramatic reduction in activity also seems to be independent of skeletal muscle type (Table S2, available at www.jneurosci.org as supplemental material) and is already evident in early development (Fig. 4A). Histochemical staining for activity within the diaphragm confirms the inability to produce active enzyme and retain it in synaptic regions of particular end organs (Fig. $4 B$ ).

For comparative purposes, we generated a second knock-out strain, acheE6, lacking exon 6 (see Materials and Methods) (Fig. S5, available at www.jneurosci.org as supplemental material). Exon 6 is essential for expression of the major spliced form of AChE found in brain and muscle (Rachinsky et al., 1990; Li et al., 1993a). In the absence of exon 6, AChE is devoid of the "tryptophan amphiphilic tetramerization" (WAT) domain (Simon et al., 1998) and cannot establish disulfide linkages to structural subunits (Massoulie et al., 2005; Noureddine et al., 2007). Therefore, when synthesized, this AChE lacks the capacity to localize to the basal lamina or the outer surface of the plasma membrane. Because exon 6 is required for the catalytic subunit to associate with structural subunits and form oligomers (Li et al., 1993a; CabezasHerrera et al., 1994), AChE expressed in this knock-out mouse appears as a hydrophilic monomeric species (Fig. S6, available at www.jneurosci.org as supplemental material). Knock-out animals with the intron regulatory region or exon 6 deleted can be compared with the total $A C h E$ knock-out, a strain now well characterized in several laboratories. The total knock-out strain is devoid of AChE in all tissues, but BuChE expression is unaltered (Xie et al., 2000; Adler et al., 2004).

\section{mRNA expression in intron 1 and exon 6 deleted}

\section{knock-out mice}

In parallel to measurements of AChE activity in muscle and CNS, we examined mRNA levels by real-time RT-PCR using primers amplifying a sequence spanning exons 2 and 3 (Fig. 4C). Deletion of the intron 1 regulatory region causes a virtual absence of AChE mRNA in muscle but leaves normal levels in the CNS. In contrast, a knock-out mouse with exon 6 deleted shows a 74\% reduction of brain AChE mRNA, yet muscle AChE mRNA is not significantly reduced. Thus, the splice to exon 6 differentially controls mRNA production and expression levels of AChE in the various tissues (Table 1). Control of expression by retaining exon 6 does not correlate precisely with mRNA levels, because the retention of $\mathrm{AChE}$ is less than what would be predicted by the reduction in mRNA (Fig. 4C, Table 1).

\section{Mouse phenotypes}

The two mouse strains, with either exon 6 or the regulatory region of intron 1 deleted, live with constant tremors. Muscle strength is sufficiently compromised to preclude prototypical measurements of muscle strength: roto-rod test, inverted screen- 


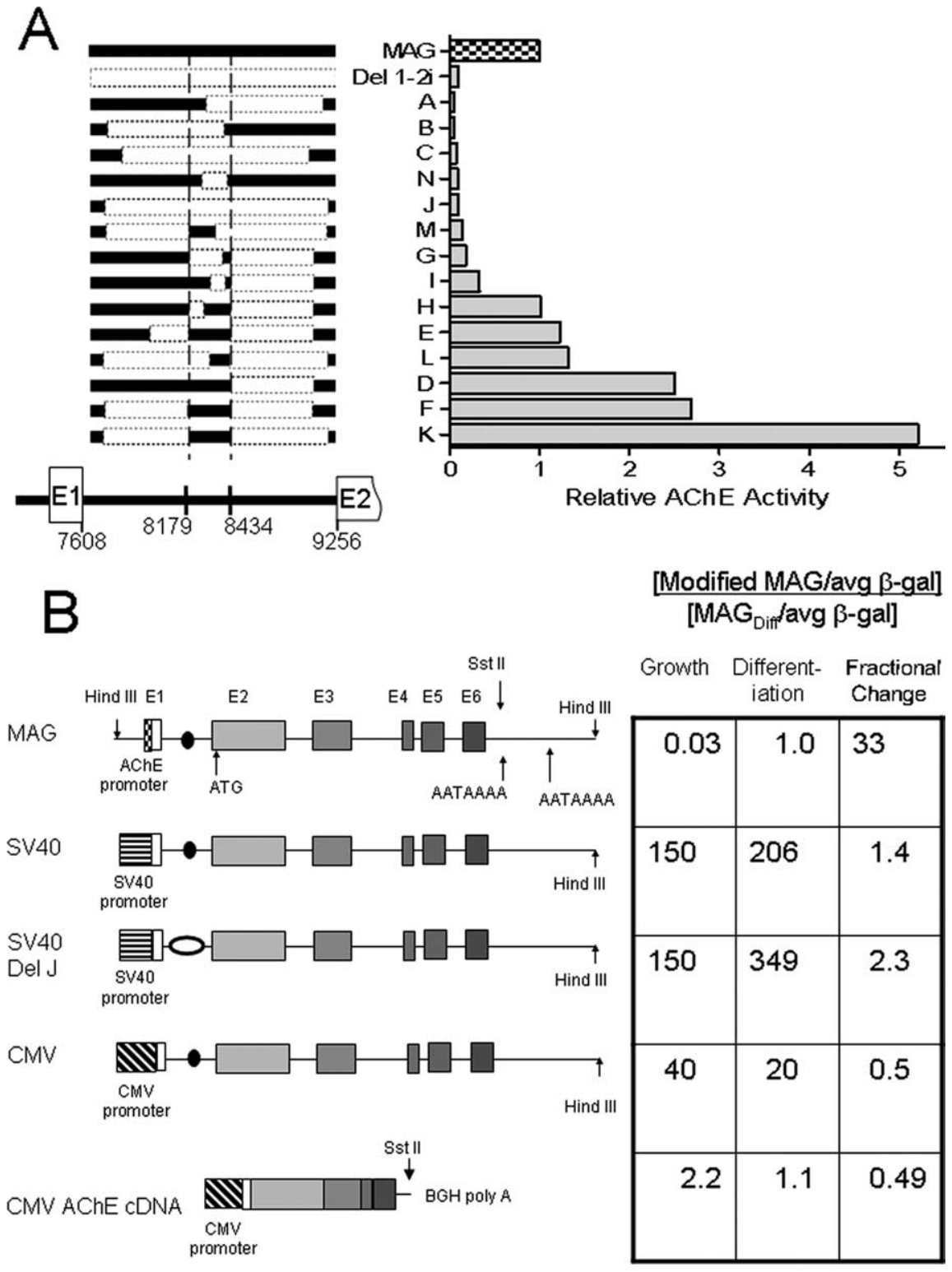

Figure 2. Deletion analysis of $A C h E$ intron 1.A, A map showing the location of alterations to the gene is on the left. Intron 1 is shown in detail; solid bars represent the unaltered genomic sequence, and open bars represent deleted regions in the reconstructed MAG. The precise locations of each intron deletion are shown in Table S1 (available at www.jneurosci.org as supplemental material). The thick dashed vertical lines show the region critical to AChE expression. Numbers refer to GenBank accession number 312033. Right, Transfected cell associated AChE activity after $4 \mathrm{~d}$ of differentiation, first normalized to a cotransfected CMV- $\beta$ galactosidase reporter construct is shown. Activity units are relative to MAG, the AChE gene sequence. $\boldsymbol{B}$, The $A C h E$ promoter is replaced by either an SV40 or CMV viral promoter, and transfected AChE activity is monitored under growth and differentiation conditions. AChE exon ORFs are shown in gray. The small black oval represents base pairs 8179-8434 in intron 1 . The checked box 5' of exon 1 in MAG represents the AChE promoter (Li et al., 1993a). The AChE promoter was replaced with either the SV40 (horizontal stripes) or the CMV (diagonal stripes) promoter at the most 5' probable cap site of $A C h E$ (base pair $\sim 7510$ ). In construct SV40 Del J, the open oval represents deletion J as pictured in A. AChE CDNA contains 60 bp of exon 1; exons 2, 3, 4, and 6 and the bovine growth hormone polyadenylation signal with no intron sequences. AChE activities are normalized to $\beta$-galactosidase activity to correct for transfection efficiency and then normalized to the corrected activity of MAG after $4 \mathrm{~d}$ of differentiation. Only the endogenous promoter produces a differentiation-dependent increase in AChE activity.

hang, or climbing an incline (Camp et al., 2005). However, the overall behavior in the enhancesome and exon 6 knock-out strains suggests that life compromises of both strains are not equivalent to those found in knocking out transcription of the entire gene. Growth rates are not as compromised as in the total gene knock-out, and animals with intron 1 regulatory region or exon 6 deleted can reproduce when mated as nullizygotes. Despite differences in AChE activity, muscle tremors appear equiv- alent in the exon 6 and intron knock-out strains. Thus, this phenotypic response may correlate most closely with the capacity of AChE to be tethered and retained at the neuromuscular junction. In both knock-out strains, neuromuscular junction $\mathrm{AChE}$ is severely compromised, but by different modes of expression. A detailed histochemical and electrophysiological analysis of the motor endplates in the two knock-out stains is underway, preliminary data has been presented in (Girard et al., 2006).

\section{AChE activity in peripheral organs} innervated by the autonomic nervous system

We also examined AChE activity in peripheral tissues innervated by the autonomic nervous system (Table S2). The small size of the paravertebral sympathetic chain in the mouse, coupled with the difficulty of removing adhering connective tissue, precludes accurate measurements of AChE activity in peripheral ganglia. However, several end organs innervated by postganglionic parasympathetic nerves have a functional cholinergic dominance. An examination of these organs shows a substantial reduction of AChE activity with removal of the intronic sequence, but the reduction is nowhere near the magnitude of that seen in skeletal muscle. Hence, AChE expression in glandular and smooth muscle containing tissues, whose innervation arises from neural crest cell development, is not as tightly controlled by the intronic region of the gene as is skeletal muscle. It should also be recognized that the tissues are composed of multiple cell types and ganglia as well as embedded post ganglionic nerve endings. Salivary gland and intestinal AChE appears nonaltered. This is also true for the adrenal medulla. Adrenal glands are innervated by sympathetic preganglionic nerves and bear an innervation resemblance to sympathetic ganglia.

AChE expression in hematopoietic cells Expression of AChE on the erythrocyte surface results from a splice to exon 5 , giving rise to a glycophospholipid-linked form on the membrane surface (Rosenberry and Scoggin, 1984), whereas the platelet incorporates this glycophospholipid-linked form on its membrane surface, as well as a soluble monomeric form in its interior (Chuang et al., 1976). Interestingly, removal of the intron 1 regulatory region yields an animal devoid of platelet AChE, but retaining normal levels in the erythrocyte (Table 1). Differential expression in hematopoietic lineages appears under control of this intronic sequence; hence, lineage control is maintained regardless of 3' splice options. 
Elements within the intron 1 regulatory region define myogenic expression of AChE

Figure 3 shows a remarkable conservation of sequence identity from mouse to man in the intron 1 regulatory region, and details well recognized transcription factor binding motifs. Returning to the $\mathrm{C} 2 \mathrm{C} 12$ cells and transfection of the $8.3 \mathrm{~kb}$ genomic fragment, we individually scrambled known motifs and monitored AChE activity after $4 \mathrm{~d}$ of differentiation. When Elk1-1 [identified either as an Elk1 site or a Stat motif (Choi et al., 2003)] or Elk 1-2 [identified as an N-box (Angus et al., 2001)] were scrambled, we observed no effect on AChE expression (Fig. 5). In contrast, scrambling either myocyte enhancer factor-2 (MEF2) (GTTATAATTAG), MRF (includes MyoD, myogenin, Myf5, and MRF4) (CAGCTG), or AT-rich [SRF/CArG-like] (CCAAAATAGc) (Chang et al., 2001) consensus motifs completely ablated differentiation-dependent AChE expression (Fig. 5).

EMSAs were used to further establish the roles of the transcription factor motifs highlighted in Figure 3. Both MEF2 (Fig. $6 A$ ) and MRF (Fig. 6B) oligonucleotide probes produced reproducible band shifts by endogenous nuclear proteins that could be supershifted with antibodies. Competition with a 50 -fold excess of cold (unlabeled) double-stranded probe identical to the labeled probe eliminated the shifted band, whereas addition of mutant or unrelated double-stranded oligos had little effect on specific binding (Fig. 6). Antibodies that produced supershifts defined the transcription factors binding to the DNA consensus motifs (Fig. 6). The MRF band shift was the most intriguing, as distinctive binding patterns emerged from extracts of myoblasts and myotubes, suggesting different binding partners for the transacting muscle regulatory factor MyoD, as identified by the supershift induced by a MyoD antibody.

Using the same conditions as those in Figure 6 for EMSA assays of the MEF2 and MRF motifs, we detected no shifts for either of the Elk motifs or the AT-rich motif. Hence, these findings with Elk1-1 and Elk1-2 are consistent with a lack of influence of these sequence motifs on AChE gene expression in the $\mathrm{C} 2 \mathrm{C} 12$ cell (Fig. 5).

Because we were unable to see a band shift with the AT-rich region probe, although scrambling of this region ablated $\mathrm{AChE}$ activity in transfection experiments (Fig. 5), we used a set of probes based on the sequence that spans both the MRF site and the neighboring AT-rich region (Fig. 3). This probe set included the wild-type sequence, each recognition motif individually scrambled to match the scrambled transfected sequences, and the doubly scrambled sequence. Band shifts of these probes seemed to be due entirely to the MRF motif (Fig. 7A) (Fig. S8, available at www.jneurosci.org as supplemental material), but surprisingly the addition of antibodies produced a supershift with an MEF2 antibody (Fig. $7 B$ ) that is not attributable to an interaction between the bound MyoD and MEF2 (Molkentin and Olson, 1996) because there is no supershift if the AT-rich region is mutated. In
Elk1-1

MEF2 MONKEY FGAGGCTCAG-CGGAAGCCCCGAGTTATAATTAGCgCCACTEGGGTTTCCTAGTTAATCT DOG GGAttTCAttCGGAAGCCCCGAGTTATAATTAGCCgCACTCGGGTTTCCTAGTTAATCC COW GGAGGCTIAG-CGGAAGCCCCGAGTTATAATTAGCCCCACTCGGGTTTCCT aGTTAATCT RAT GAGGCGCAG-CGGAAGCCCCGAGTTATAATTAGCCCCACTCGG-TTTCCTGGTTAATCT

MONKEY CCAgCAgCatCACCACC-1.- - CCCAGC-tCAGGacagtgGG- - GGCTGG

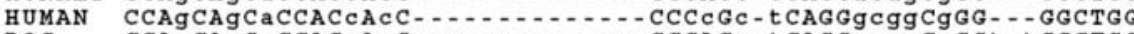
CCACCACCaCCACCACCaccaccaccaccacCCCAGcctCAGGgcggCgGGt-tGGCTGG DAT CCATCACCaCCACC-..- CAGC - tCAGGacggCgaG-- - GaCTGC

MONKEY GCGAgGGGTGACCGgCgGgaGAGGGGGgAGTTCCCACCCGGGGAATTTTGATCCTTTGGC HUMAN GCtAgGaGTGACCGgCgGgaGAGGGGGgAGTTCCCACCCGGGGAATTTTGATCCTTTGGC COW RAT GtGAtGGGTGAACGCCCG--GAGGGGGTAGTTCCgACCCGGGGAATTTTGATCTCTTGGC

MONKEY TGGAGATGCCGGAACCG TAACAGCTGCTGCCCCCAAAATAGCGCCCCCGCCCCTGCaGCC Elk1-2 MRF AT-rich

HUMAN TGGAGATGCCGGAACCG AGCAGCTGCTGCCCCCAAAATAGCGCCCCEGCCCCTGCaGCC

RAT TGGAGATGCCGGAACCgCAGCAGCTGCTGCCCC-AAAATAGCGCCCCEGCCCTGCaGCC TGGAGA GCCGGAACt A CAGCAGCTGtTGCCCCCAAAATAGCGCCCCtGCCt TGCtGCTGGAGACGCCGGAACT CAGCAGCTGTTGCCCCCAAAATAGCGCCCCEGCCtTGCtaC-
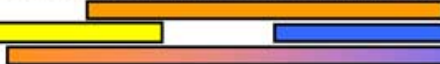

MONKEY GGGGATCTCCGGAGCCCCggGAACaCAagCGTCCtGGCTCGCCC-TTCAgg

HUMATTCTCCGGAGtCCCggGAACgCAGgCGTCCGGCTCGCCC-TTCAgg GGGGATCTCCGGAGCtCCCgGAACaCAGaCGTCCtGGCTCGCCCCTTCAat

Figure 3. AChE gene sequence comparisons. The intron 1 regulatory region (large black brackets) in the AChE gene is comgene sequence. DNA consensus binding motifs for transcription factors that were studied in this report are highlighted. Colored bars underlining sequence elements represent probes used in EMSA.

addition, the AT-rich region did not interact with either of the SRF antibodies we tested (Fig. S9, available at www.jneurosci.org as supplemental material) in either myoblast or myotube extracts.

\section{Discussion}

\section{Gene expression and alternative mRNA processing}

A single $A C h E$ gene subserves all central and peripheral cholinergic function, regardless of whether acetylcholine-elicited responses are mediated by nicotinic, muscarinic receptors or possibly nonneural signaling mechanisms. The distinct $\mathrm{C}$ termini of the three alternatively spliced forms of $A C h E$ do not affect catalytic mechanism; they only provide appropriate recognition sequences for oligomerization of the catalytic subunits, either for attaching a glycophospholipid link or facilitating association with distinct proline-rich structural subunits. Details of the splicing mechanisms and patterns have been investigated in several laboratories (Li et al., 1993a; Luo et al., 1998; Legay et al., 1999), and the multiple spliced forms have been found in various tissues and synaptic junctional areas.

What has been less clear in the regulation of AChE levels have been mechanisms of differentiation-controlled expression in muscle, nerve, and hematopoietic systems. By using combined cell culture and in vivo homologous recombination investigations, we characterized a critical intronic sequence, residing between the first and second exons, that acts in an enhancesome capacity, selectively interacting with the endogenous promoter to control expression specifically in skeletal muscle and hematopoietic lineages. 
Table 1. AChE activity from wild-type $(+/+)$, achei1 $\operatorname{rr}^{\mathrm{FLOXED}}(-/-)$, achei1rr(-/-), and acheE6 mice

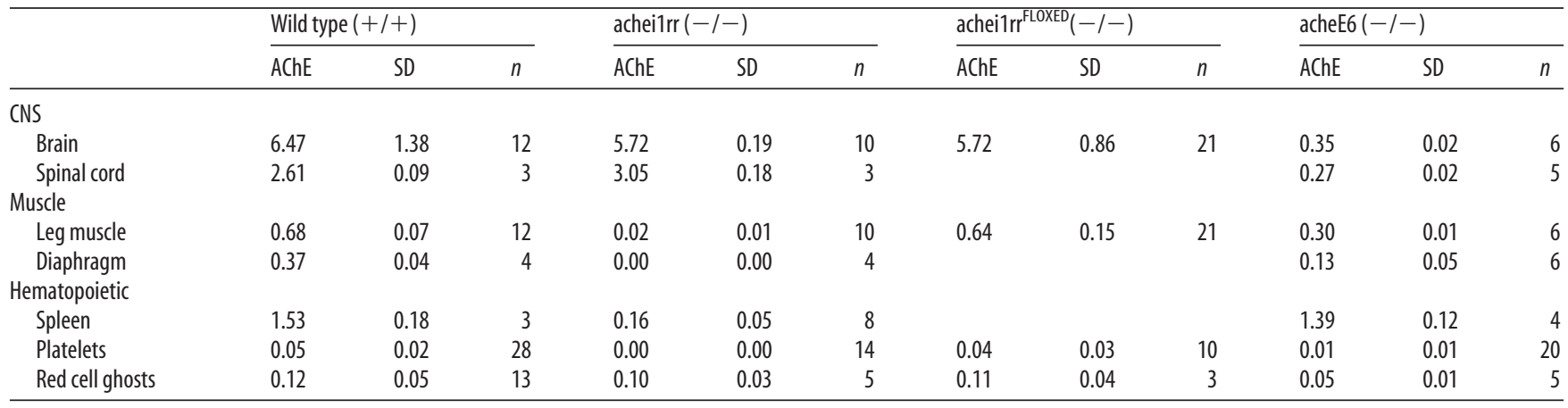

AChE activities as the mean of $n$ values with error expressed as SD are shown. Activity is expressed as units of AChE per gram of tissue. For erythrocyte ghosts and platelets, mean AChE activity is expressed as units of AChE per milliliter of blood.
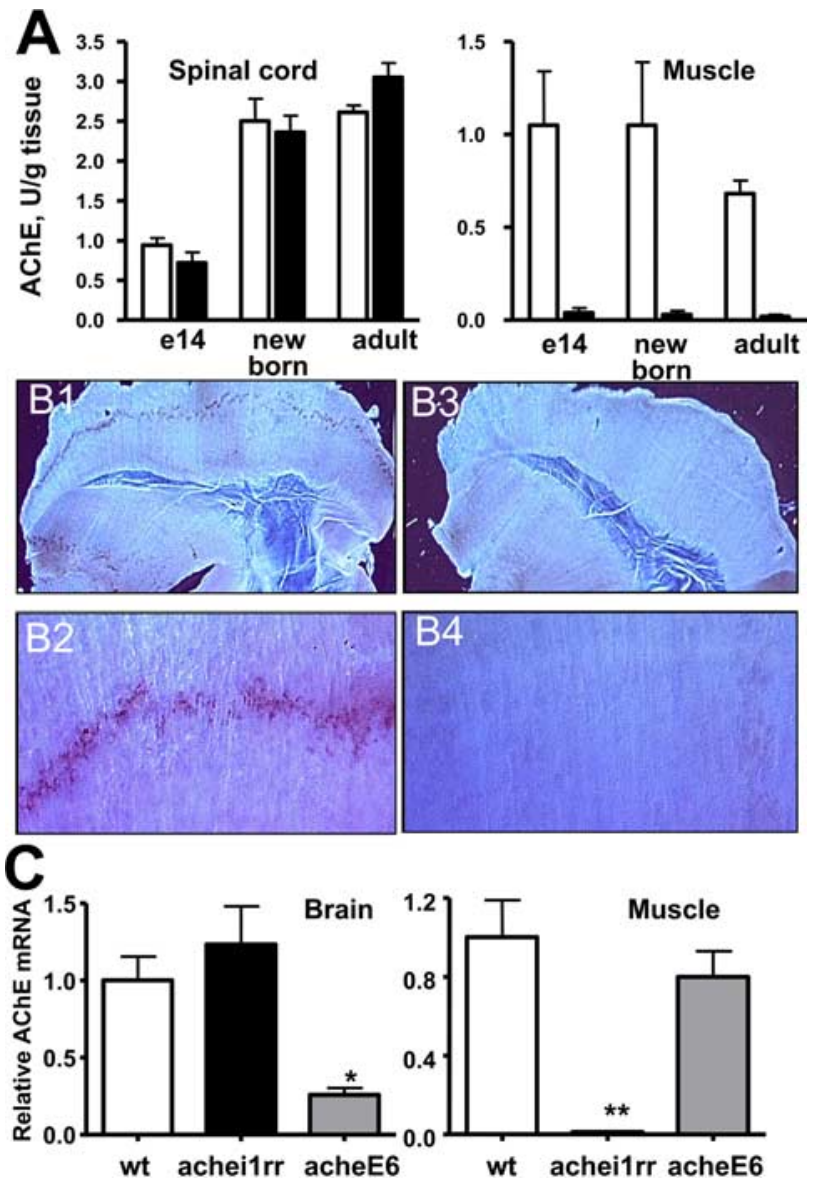

Figure 4. AChE expression in mouse tissues. $A$, AChE activity in embryonic, newborn, and adult wild-type $(+/+)$ and achei1rr $(-/-)$ mice. Activity is expressed as units of AChE per gram of tissue. AChE is expressed as means, and error bars represent SDs of the mean. Open bars represent AChE from wild-type mice, and solid bars represent achei1rr (-/-) mice. $\boldsymbol{B}$, Karnovsky-Roots stain for AChE in diaphragm muscle from wild-type and achei1rr (-I-) knock-out mice. Panels 1 and 2 are from wild-type mice. Panels 3 and 4 are from achei1rr $(-/-)$ knock-out mice. Panels 1 and 3 show whole diaphragm at $7.5 \times$ magnification, and 2 and 4 show a $16 \times$ magnification of the mid-diaphragm innervated region. C, Real-time RT-PCR quantification of AChE mRNA. Relative levels of AChE mRNA in brain and leg muscle of adult wild-type $(n=6)$, achei1rr $(-/-)(n=3)$, and acheE6 $(-/-)(n=5)$ knock-out mice. For each tissue, fold difference in the AChE $\mathrm{mRNA} / c y c l o p h i l i n$ ratio is compared with wild-type mice. The values for achei1 $\operatorname{rr}(-/-)$ mRNA in muscle are $1.1 \%$ of control values. Error bars represent SD of the mean ( $t$ test; $\left.{ }^{*} p=0.0022 ;{ }^{* *} p=0.0087\right)$.

Previous studies with reporter genes and run-on transcription have revealed small changes in expression through transcriptional enhancement and mRNA stabilization (Angus et al., 2001). The critical role played by this intron and its selective interaction

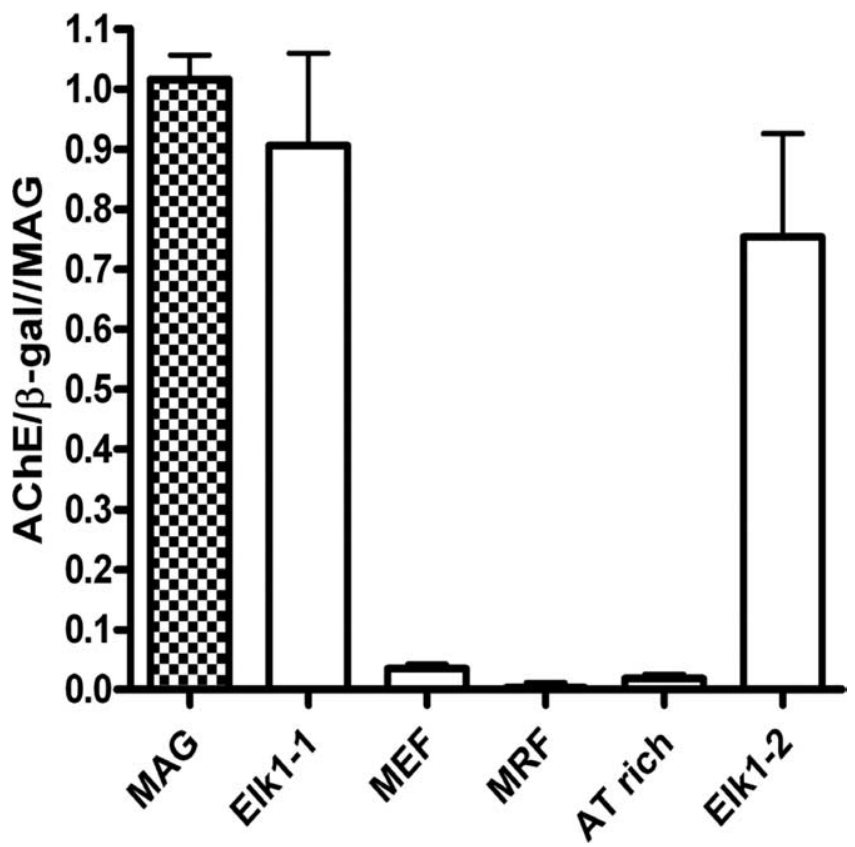

Scrambled transcription motif

Figure 5. AChE expression analysis of MAG constructs with scrambled transcription motifs. Transcription factor binding consensus sequences in Figure 3 were individually scrambled and substituted for the wild-type sequence in the MAG genomic construct (see supplemental data, available at www.jneurosci.org as supplemental material). Modified MAG genes were transfected into $\mathrm{C} 2 \mathrm{C} 12$ myoblasts and then analyzed after $4 \mathrm{~d}$ of differentiation. All cell-associated AChE activity was normalized to cotransfected $\beta$-galactosidase and the parent construct MAG. The bars show the means of five transfections. Error bars represent SD.

with the promoter region in tissue-specific expression could only be demonstrated fully by dissecting the intact gene in cell culture and examining the function of the intronic region in knock-out mouse strains with selective deletions of the intron and alternatively spliced exons.

Characterizing the enhancesome activity of intron 1

Parallel studies in differentiating mouse muscle (C2C12) cell culture and homologous recombination to delete specific segments of the gene in intact mice initially identified a region in the $A C h E$ gene that selectively controls expression in skeletal muscle and hematopoietic cells. Studies in C2C12 cells revealed that control by the intron requires the endogenous promoter and proximal positioning to obtain tissue-specific expression. These findings underscore the importance of using the intact gene to analyze gene expression comprehen- 


\section{A MEF2 motif probe}

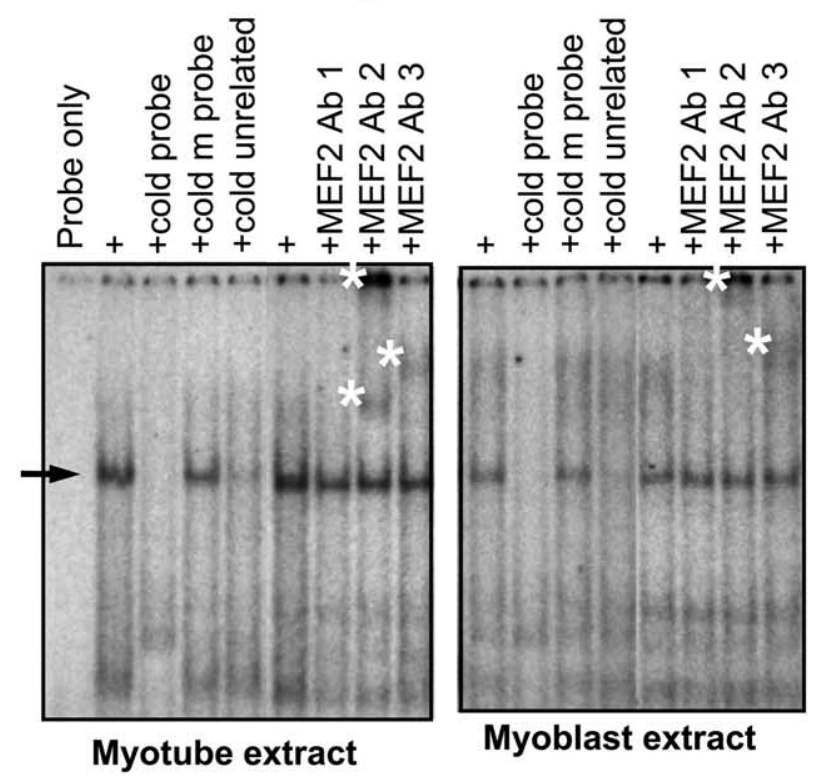

\section{B MRF motif probe}

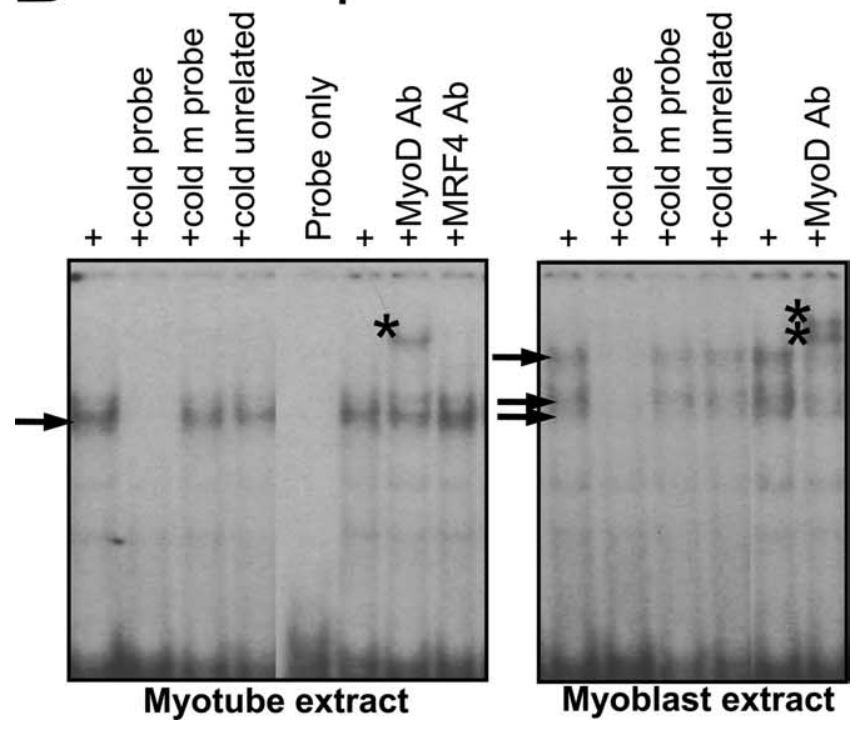

Figure 6. EMSA of MEF2 and MRF DNA binding motifs from the intron 1 regulatory region. Probes (Fig. 3, underlined regions) were labeled with ${ }^{32} \mathrm{P}$ and then incubated with nuclear extracts from either $\mathrm{C} 2 \mathrm{C} 12$ myoblasts or myotubes. All binding reactions included nuclear extract (marked with a + ), except those labeled probe only. Solid black arrows mark the location of shifted bands. Cold probes were included in the incubations at $\sim 50$-fold molar excess over the labeled probe in the "+ cold probe" lanes. Cold mutant probes contain the mutant sequence transfected in Figure 5. Antibodies are identified in Materials and Methods. Supershifts caused by antibody binding are marked by an asterisk to the left and slightly above the band. $\boldsymbol{A}$, EMSA with MEF2 probe. Binding patterns produced by extracts from myoblasts and myotubes appear to be the same, but myoblasts produce less binding of the MEF2 sequence. $B$, EMSA with MRF probe. Supershift identifies MyoD as the transcription factor binding to the MRF oligonucleotide.

sively. Accordingly, the knock-out mouse strain developed by homologous recombination reveals that the compact AChE gene in mammals not only regulates its expression and tissue distribution through a complex mechanism of alternative splicing (Li et al., 1991) but also through regulatory relation- ships between its promoter and sequence conserved enhancer regions in intron 1. Hence, an intron (Klamut et al., 1997; Wang et al., 2002) within the AChE gene contains the regulatory elements that interact with its endogenous promoter.

Conservation of distinct sequence components in the intron and the interdependencies between intron and promoter described here conform to an "enhancesome" model of gene regulation (Merika and Thanos, 2001; Arnosti and Kulkarni, 2005). The interrelationship between the promoter and multiple intronic elements, both silencers and enhancers or activators that produce selective $\mathrm{AChE}$ expression, establishes that regulation does not depend on a single cis-acting enhancer or promoter sequence. The deleted 255 bp region contains multiple regulatory motifs that are also identified by sequence conservation from mouse to man (Fig. 3). Candidate motifs include the MEF2-box as well as an E-box that has been described previously (Angus et al., 2001). Although it would be prohibitively expensive to knock-out individual regions of this sequence by homologous recombination, the intron knock-out animal reveals the critical importance of this region in selective muscle expression.

The exon 6 knock-out mouse, showing diminished brain AChE mRNA levels, as well as findings of Deschenes-Furry et al. (2005) that implicate regulation by an AU-rich element in the $3^{\prime}$-UTR of the gene, provide evidence for multiple regions in the AChE gene that influence gene expression. Deletion of the $3^{\prime}$ UTR of the $A C h E$ gene produces only a modest decrease in expressed activity (Fig. S1, available at www.jneurosci.org as supplemental material), suggesting only a limited supporting role of this region in the differentiation-dependent muscle expression in C2C12 cells.

The knock-out strains not only provide new information on regulation of $A C h E$ gene expression during muscle differentiation but allow examination of the phenotype of animals with normal levels of AChE in brain and spinal cord, but devoid of skeletal muscle AChE from birth. Accordingly, compensatory changes in synaptic structure, innervation, and acetylcholine receptor levels can be examined to ascertain whether compensatory synaptic structural changes are associated with muscle AChE activity or protein (Girard et al., 2006).

Origin of acetylcholinesterase in the neuromuscular junction The origin of AChE in muscle endplates has been an area of long-standing investigation (Anglister and McMahan, 1985; Grinnell, 1995; Rotundo et al., 1997; Jevsek et al., 2004; Mis et al., 2005). Previous work has shown AChE expression in motor neurons to be present along the axon (Massoulie and Bon, 1982; Rotundo and Carbonetto, 1987). In addition, asymmetric forms of the enzyme, present in synapses, have also been found in the motoneuron (Di Giamberardino and Couraud, 1978; Fernandez et al., 1979; Torres et al., 1983). Skeletal muscle myotubes in culture will secrete the asymmetric forms of AChE after differentiation (Inestrosa et al., 1982). Coculture experiments where orthologous forms of AChE are produced from nerve explants of different species suggest that both nerve and muscle are contributory to synaptic AChE with muscle being the dominant contributor (Mis et al., 2005). Our identification of an intronic region of the gene controlling AChE expression in skeletal muscle, but not the innervating nerve cell, indicates that the muscle alone would be the origin of $\mathrm{AChE}$ in the motor end plate; the same conclusion is reached if one compares spinal cord and muscle AChE mRNA levels (Fig. 4C). The involvement of innervation may be re- 

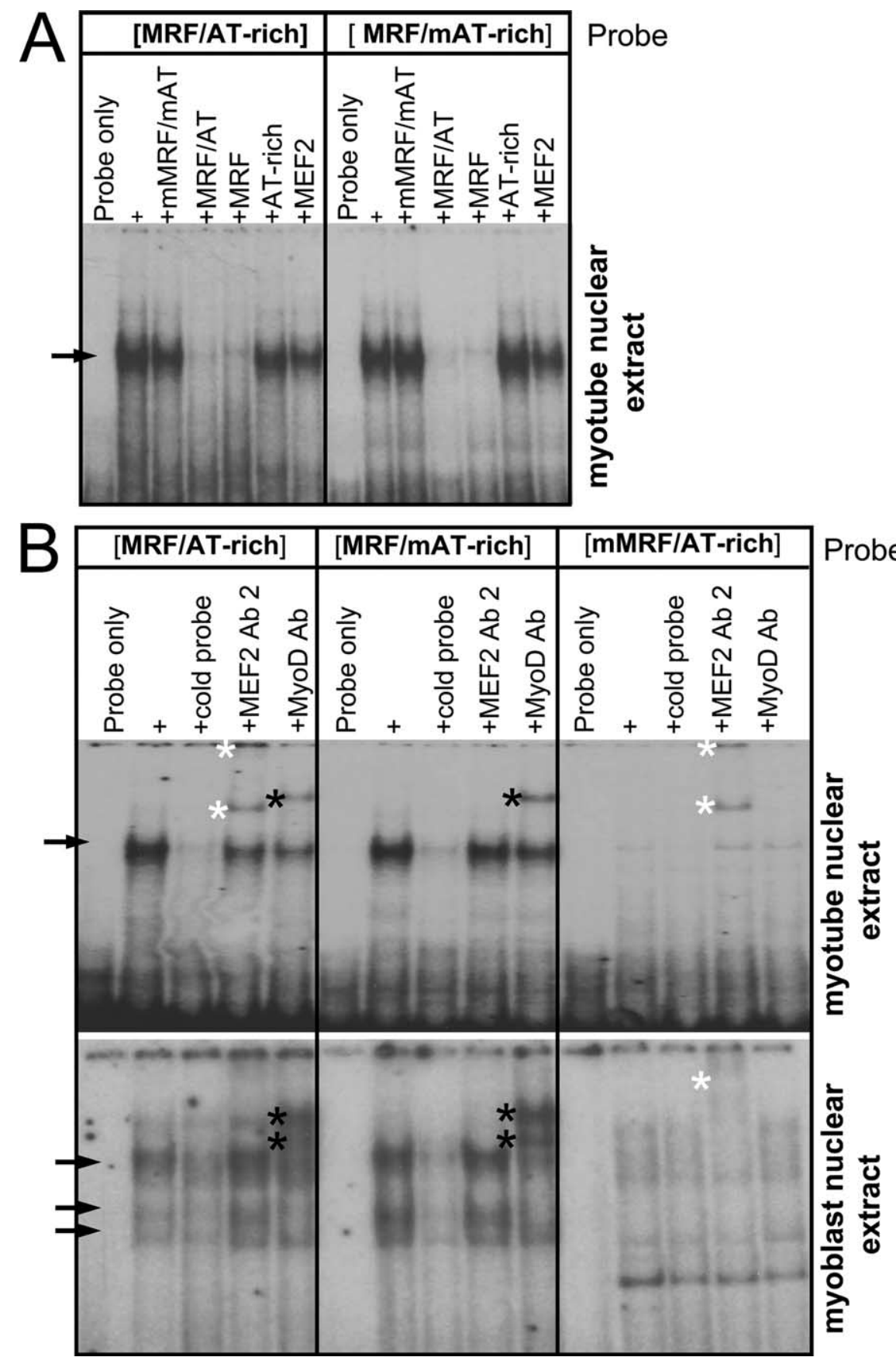

Figure 7. EMSA with probes encompassing both MRF and AT-rich motifs. The sequence analyzed by ${ }^{32}$ P-labeled double-stranded DNA probes is indicated by the orange to blue shaded line in Figure 3 ; it covers both the MRF and AT-rich motifs. Wild-type sequence (MRF/AT-rich), as well as mutant (m) variations mMRF/AT-rich and MRF/mAT-rich were used as probes; $\mathrm{mMRF} / \mathrm{mAT}$-rich was used only in competition experiments. Probes were incubated with nuclear extracts as indicated to the right of the autoradiograph. Labeled probes are shown in bold at the top of each panel; competing probes or antibodies are shown in the vertical orientation. $A$, MRF/AT-rich and MRF/mAT-rich probes were run in parallel. Competition using a 50-fold excess of five probes is shown. mMRF/mAT-rich and MRF/AT-rich probes include two sites, whereas MRF, AT-rich, and MEF2 probes contain only a single site. Only the myotube nuclear extract results are shown (myoblast and myotube data can be compared in Fig. S8, available at www.jneurosci.org as supplemental material). $\boldsymbol{B}$, Supershift with antibodies. Binding reactions with myotube and myoblast nuclear extracts are shown. The cold probe used for competition was MRF/AT-rich in all cases. Band shifts are indicated by bold arrows. Supershifts are marked by asterisks. MEF2 supershift is shown in white, and MyoD supershift is shown in black.

stricted to maintaining an attachment matrix for the exported AChE by the muscle cell. In turn, the basal lamina anchor could influence turnover of the gene product by recruiting parasynaptic AChE into a stable synaptic structure and en- trapping AChE synthesized by junctional nuclei. Accordingly, subsynaptic nuclei may be influenced by trans-acting factors controlling the interaction of the AChE promoter with an enhancer region.

\section{Control of hematopoietic expression}

Hematopoietic cell differentiation into distinct lineages has been demonstrated to be controlled by transcriptional events (Perry and Soreq, 2002; Kaushansky, 2005). It would be of interest to know whether AChE expression in hematopoietic lineages is simply a marker of differentiation or a regulator of expression. We show here that differential expression of AChE in the megakaryocyte lineage is controlled by the enhancesome region in intron 1. Control of expression appears independent of the alternative $A C h E$ splice variant expressed in the mouse platelet, where we observe all three $3^{\prime}$-splice options (our unpublished observations). It will ultimately be of interest to determine whether hematopoietic cells and muscle use the same or distinct consensus sequences within the enhancesome to control expression.

\section{Transcription factor motifs within the enhancesome}

Within the conserved intron 1 regulatory sequence of the $A C h E$ gene, at least three transcription factor binding motifs participate in control of muscle-specific expression during differentiation. These motifs bind muscle regulatory factors, which, in the case of the AChE gene MyoD (Angus et al., 2001), and MEF2 (Black and Olson, 1998), appear dominant. MyoD is known to interact with E-proteins (HEB/HTF4, E2-2/ITF-2, and E12/E47) forming heterodimers, and transcriptional activation of the MyoD-E-protein complexes are affected by members of the MEF2 family of transcription factors (Black et al., 1998). Both motifs are clearly critical to differentiation associated AChE expression as shown by both scrambling these sequences (Fig. 5) and by binding of transacting factors shown in band shifts (Figs. $6,7)$.

Resolving the role of a third motif, the AT-rich sequence just 6 bp $3^{\prime}$ of the active MyoD binding site, is not as straightforward. This DNA sequence resembles a serum responsive element (Galvagni et al., 1997; Li et al., 2005) or more likely a hybrid serum responsive factor and MEF2 binding element (L'Honore et al., 2007). The sequence is clearly critical to $A C h E$ transcriptional activation, because scrambling the DNA sequence through this region ablates AChE activity (Fig. 5), yet EMSA with this DNA 

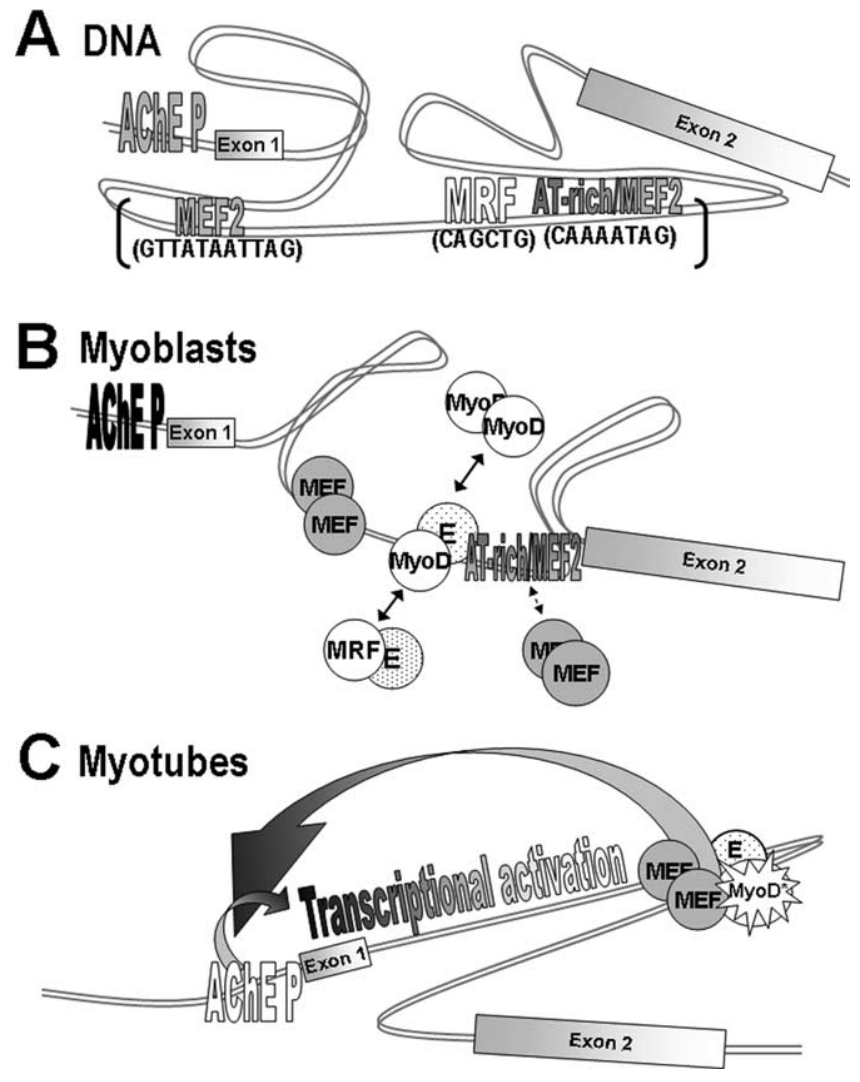

Figure 8. Proposed mechanistic interaction between the promoter and the enhancesome in intron 1. A, The relative positions of several important features of the $5^{\prime}$-end of the AChE gene are shown. The promoter is 5' of exon 1 (AChE P) (Li et al., 1993b). Relevant MRF and MEF2 sites in the intron 1 regulatory region are shown. Exons 1 and 2 flank intron 1. B, Occupation of intronic transcription factor binding motifs in myoblasts. EMSAs with nuclear extracts from myoblasts show binding to the $5^{\prime}$ MEF2 site that can be supershifted by MEF2 antibodies. The MRF motif binding pattern is more complex: there are multiple shifted bands, some of which supershift with MyoD; others do not, suggesting that multiple MRFs can bind to this consensus region. In addition, distinct E-proteins present during different stages of development likely partner with the MRFs. The more 3' MEF2 motif binds its transcription factor with lower affinity. $C$, In myotubes, MyoD finds its proper E-protein binding partner and perhaps because of the enhancesome-like nature of this intronic region, or the presence of newly synthesized accessory binding proteins, MEF2 is able to properly activate MyoD. In turn, myogenic transcriptional activation of the AChE gene is affected.

motif did not produce a specific band shift. Additional analysis showed that DNA-MEF2 binding could be stabilized or enhanced with an antibody, suggesting a weaker interaction that could depend on other transcription factors and accessory proteins gathered at the enhancesome.

Accordingly, we defined three conserved regions that control expression through the binding of MEF2 and MyoD. All three of these regions are required to be intact to achieve enhanced transcription. Moreover, EMSAs show specific interactions with each consensus sequence, and the transacting elements can be defined by antibody supershifts. In contrast, other conserved consensus sequences, Elk1-1 and Elk1-2, when scrambled, did not appear to affect transcription. Because Elk1-2 has been defined as an N-box and was thought to be a controlling element (Chan et al., 1999), we scrambled the sequence in multiple permutations (see supplemental data, available at www.jneurosci.org as supplemental material). None significantly influenced gene expression.

Although we have yet to ascertain whether the same intronic elements affect transcription in hematopoietic cells, our platelet studies show that this enhancer region functions independently of splice variation and can control expression differently within the lineage.

Our findings on the intron elements controlling expression differ somewhat from those of Angus et al. (2001), who found by deletion or mutagenesis that Elk1-2 (N-box) influences expression when various reporter constructs are used in cell culture or after injection in muscle. In contrast, we found no evidence in the C2C12 cell for control of expression by the N-box, when the full-length gene is used to assess expression in differentiating muscle cells (Fig. 5).

The influence of intron 1 functioning only with the endogenous promoter in the intact gene (Fig. 2), the tissue-specific and dramatic differences revealed in the AChE intron regulatory region knock-out animal, and demonstration of an involvement of MEF2, MRF, and AT-rich sequences (Fig. 8) all point to intron 1 exerting dominant control of $A C h E$ gene expression in muscle.

\section{References}

Adler M, Manley HA, Purcell AL, Deshpande SS, Hamilton TA, Kan RK, Oyler G, Lockridge O, Duysen EG, Sheridan RE (2004) Reduced acetylcholine receptor density, morphological remodeling, and butyrylcholinesterase activity can sustain muscle function in acetylcholinesterase knockout mice. Muscle Nerve 30:317-327.

Anglister L, McMahan UJ (1985) Basal lamina directs acetylcholinesterase accumulation at synaptic sites in regenerating muscle. J Cell Biol 101:735-743.

Angus LM, Chan RY, Jasmin BJ (2001) Role of intronic E- and N-box motifs in the transcriptional induction of the acetylcholinesterase gene during myogenic differentiation. J Biol Chem 276:17603-17609.

Arnosti DN, Kulkarni MM (2005) Transcriptional enhancers: intelligent enhanceosomes or flexible billboards? J Cell Biochem 94:890-898.

Atanasova E, Chiappa S, Wieben E, Brimijoin S (1999) Novel messenger RNA and alternative promoter for murine acetylcholinesterase. J Biol Chem 274:21078-21084.

Black BL, Olson EN (1998) Transcriptional control of muscle development by myocyte enhancer factor-2 (MEF2) proteins. Annu Rev Cell Dev Biol 14:167-196.

Black BL, Molkentin JD, Olson EN (1998) Multiple roles for the MyoD basic region in transmission of transcriptional activation signals and interaction with MEF2. Mol Cell Biol 18:69-77.

Buratowski S, Chodosh LA (2001) Mobility shift DNA-binging assay using gel electrophoresis. In: Current protocols in molecular biology, Chap 12, Unit 12.1 (Ausubel FM, Brent R, Kingston RE. Moore D, Seidman JG, Smith JA, Struhl K, eds). Hoboken, NJ: Wiley Interscience.

Cabezas-Herrera J, Moral-Naranjo MT, Campoy FJ, Vidal CJ (1994) G4 forms of acetylcholinesterase and butyrylcholinesterase in normal and dystrophic mouse muscle differ in their interaction with Ricinus communis agglutinin. Biochim Biophys Acta 1225:283-288.

Camp S, Zhang L, Marquez M, de la Torre B, Long JM, Bucht G, Taylor P (2005) Acetylcholinesterase (AChE) gene modification in transgenic animals: functional consequences of selected exon and regulatory region deletion. Chem Biol Interact 157-158:79-86.

Chan RY, Boudreau-Lariviere C, Angus LM, Mankal FA, Jasmin BJ (1999) An intronic enhancer containing an N-box motif is required for synapseand tissue-specific expression of the acetylcholinesterase gene in skeletal muscle fibers. Proc Natl Acad Sci USA 96:4627-4632.

Chang PS, Li L, McAnally J, Olson EN (2001) Muscle specificity encoded by specific serum response factor-binding sites. J Biol Chem 276:17206-17212.

Choi RC, Siow NL, Cheng AW, Ling KK, Tung EK, Simon J, Barnard EA, Tsim KW (2003) ATP acts via P2Y1 receptors to stimulate acetylcholinesterase and acetylcholine receptor expression: transduction and transcription control. J Neurosci 23:4445-4456.

Chuang HY, Mahammad SF, Mason RG (1976) Acetylcholinesterase, choline acetyltransferase, and the postulated acetylcholine receptor of canine platelets. Biochem Pharmacol 25:1971-1977. 
Chui D, Oh-Eda M, Liao YF, Panneerselvam K, Lal A, Marek KW, Freeze HH, Moremen KW, Fukuda MN, Marth JD (1997) Alpha-mannosidase-II deficiency results in dyserythropoiesis and unveils an alternate pathway in oligosaccharide biosynthesis. Cell 90:157-167.

Deschenes-Furry J, Belanger G, Mwanjewe J, Lunde JA, Parks RJ, PerroneBizzozero N, Jasmin BJ (2005) The RNA-binding protein HuR binds to acetylcholinesterase transcripts and regulates their expression in differentiating skeletal muscle cells. J Biol Chem 280:25361-25368.

Di Giamberardino L, Couraud JY (1978) Rapid accumulation of high molecular weight acetylcholinesterase in transected sciatic nerve. Nature 271:170-172.

Dodge JT, Mitchell C, Hanahan DJ (1963) The preparation and chemical characteristics of hemoglobin-free ghosts of human erythrocytes. Arch Biochem Biophys 100:119-130.

Duval N, Massoulie J, Bon S (1992) H and T subunits of acetylcholinesterase from Torpedo, expressed in COS cells, generate all types of globular forms. J Cell Biol 118:641-653.

Ellman GL, Courtney KD, Andres Jr V, Feather-Stone RM (1961) A new and rapid colorimetric determination of acetylcholinesterase activity. Biochem Pharmacol 7:88-95.

Feng Y, Carlson CG (1994) Changes in the endplate accumulation of acetylcholinesterase during synapse elimination in the mouse. Brain Res Dev Brain Res 79:151-156.

Fernandez HL, Duell MJ, Festoff BW (1979) Cellular distribution of $16 \mathrm{~S}$ acetylcholinesterase. J Neurochem 32:581-585.

Fuentes ME, Taylor P (1993) Control of acetylcholinesterase gene expression during myogenesis. Neuron 10:679-687.

Galvagni F, Lestingi M, Cartocci E, Oliviero S (1997) Serum response factor and protein-mediated DNA bending contribute to transcription of the dystrophin muscle-specific promoter. Mol Cell Biol 17:1731-1743.

Gilman M (2001) Ribonuclease protection assay. In: Current protocols in molecular biology, Chap 4, Unit 4.7 (Ausubel FM, Kingston RE, Moore D, Seidman JG, Smith JA, Struhl K, eds). Hoboken, NJ: Wiley Interscience.

Girard E, Bernard V, Camp S, Taylor P, Krejci E, Molgo J (2006) Remodeling of the neuromuscular junction in mice with deleted exons 5 and 6 of acetylcholinesterase. J Mol Neurosci 30:99-100.

Grinnell AD (1995) Dynamics of nerve-muscle interaction in developing and mature neuromuscular junctions. Physiol Rev 75:789-834.

Inestrosa NC, Silberstein L, Hall ZW (1982) Association of the synaptic form of acetylcholinesterase with extracellular matrix in cultured mouse muscle cells. Cell 29:71-79.

Inestrosa NC, Miller JB, Silberstein L, Ziskind-Conhaim L, Hall ZW (1983) Developmental regulation of $16 \mathrm{~S}$ acetylcholinesterase and acetylcholine receptors in a mouse muscle cell line. Exp Cell Res 147:393-405.

Jevsek M, Mars T, Mis K, Grubic Z (2004) Origin of acetylcholinesterase in the neuromuscular junction formed in the in vitro innervated human muscle. Eur J Neurosci 20:2865-2871.

Jones-Villeneuve EM, Rudnicki MA, Harris JF, McBurney MW (1983) Retinoic acid-induced neural differentiation of embryonal carcinoma cells. Mol Cell Biol 3:2271-2279.

Joyner AL (2000) Gene targeting, Ed 2. New York: Oxford UP.

Karolchik D, Baertsch R, Diekhans M, Furey TS, Hinrichs A, Lu YT, Roskin KM, Schwartz M, Sugnet CW, Thomas DJ, Weber RJ, Haussler D, Kent WJ (2003) The UCSC genome browser database. Nucleic Acids Res 31:51-54.

Kaushansky K (2005) The molecular mechanisms that control thrombopoiesis. J Clin Invest 115:3339-3347.

Kent WJ (2002) BLAT-the BLAST-like alignment tool. Genome Res 12:656-664.

Klamut HJ, Bosnoyan-Collins LO, Worton RG, Ray PN (1997) A musclespecific enhancer within intron 1 of the human dystrophin gene is functionally dependent on single MEF-1/E box and MEF-2/AT-rich sequence motifs. Nucleic Acids Res 25:1618-1625.

Legay C, Mankal FA, Massoulie J, Jasmin BJ (1999) Stability and secretion of acetylcholinesterase forms in skeletal muscle cells. J Neurosci 19:8252-8259.

L'Honore A, Rana V, Arsic N, Franckhauser C, Lamb NJ, Fernandez A (2007) Identification of a new hybrid serum response factor and myocyte enhancer factor 2-binding element in MyoD enhancer re- quired for MyoD expression during myogenesis. Mol Biol Cell 18:1992-2001.

Li B, Sedlacek M, Manoharan I, Boopathy R, Duysen EG, Masson P, Lockridge $\mathrm{O}$ (2005) Butyrylcholinesterase, paraoxonase, and albumin esterase, but not carboxylesterase, are present in human plasma. Biochem Pharmacol 70:1673-1684.

Li Y, Camp S, Rachinsky TL, Getman D, Taylor P (1991) Gene structure of mammalian acetylcholinesterase. Alternative exons dictate tissue-specific expression. J Biol Chem 266:23083-23090.

Li Y, Camp S, Taylor P (1993a) Tissue-specific expression and alternative mRNA processing of the mammalian acetylcholinesterase gene. J Biol Chem 268:5790-5797.

Li Y, Camp S, Rachinsky TL, Bongiorno C, Taylor P (1993b) Promoter elements and transcriptional control of the mouse acetylcholinesterase gene. J Biol Chem 268:3563-3572.

Livak KJ, Schmittgen TD (2001) Analysis of relative gene expression data using real-time quantitative PCR and the 2(-Delta Delta $\mathrm{C}(\mathrm{T})$ ) method. Methods 25:402-408.

Luo ZD, Camp S, Mutero A, Taylor P (1998) Splicing of 5' introns dictates alternative splice selection of acetylcholinesterase pre-mRNA and specific expression during myogenesis. J Biol Chem 273:28486-28495.

Malcolm B, Wang W (1999) Two-stage PCR protocol allowing introduction of multiple mutations, deletions and insertions using QuikChange site-directed mutagenesis. BioTechniques 26:680-682.

Massoulie J (2002) The origin of the molecular diversity and functional anchoring of cholinesterases. NeuroSignals 11:130-143.

Massoulie J, Bon S (1982) The molecular forms of cholinesterase and acetylcholinesterase in vertebrates. Annu Rev Neurosci 5:57-106.

Massoulie J, Bon S, Perrier N, Falasca C (2005) The C-terminal peptides of acetylcholinesterase: cellular trafficking, oligomerization and functional anchoring. Chem Biol Interact 157-158:3-14.

Merika M, Thanos D (2001) Enhanceosomes. Curr Opin Genet Dev 11:205-208.

Meshorer E, Toiber D, Zurel D, Sahly I, Dori A, Cagnano E, Schreiber L, Grisaru D, Tronche F, Soreq H (2004) Combinatorial complexity of 5 alternative acetylcholinesterase transcripts and protein products. J Biol Chem 279:29740-29751.

Mis K, Mars T, Jevsek M, Strasek H, Golicnik M, Brecelj J, Komel R, King MP, Miranda AF, Grubic Z (2005) Expression and distribution of acetylcholinesterase among the cellular components of the neuromuscular junction formed in human myotube in vitro. Chem Biol Interact 157-158:29-35.

Molkentin JD, Olson EN (1996) Combinatorial control of muscle development by basic helix-loop-helix and MADS-box transcription factors. Proc Natl Acad Sci USA 93:9366-9373.

Mutero A, Camp S, Taylor P (1995) Promoter elements of the mouse acetylcholinesterase gene. Transcriptional regulation during muscle differentiation. J Biol Chem 270:1866-1872.

Noureddine H, Schmitt C, Liu W, Garbay C, Massoulie J, Bon S (2007) Assembly of acetylcholinesterase tetramers by peptidic motifs from the proline-rich membrane anchor, PRiMA: competition between degradation and secretion pathways of heteromeric complexes. J Biol Chem 282:3487-3497.

Perry C, Soreq H (2002) Transcriptional regulation of erythropoiesis. Fine tuning of combinatorial multi-domain elements. Eur J Biochem 269:3607-3618.

Rachinsky TL, Camp S, Li Y, Ekstrom TJ, Newton M, Taylor P (1990) Molecular cloning of mouse acetylcholinesterase: tissue distribution of alternatively spliced mRNA species. Neuron 5:317-327.

Radic Z, Taylor P (2006) Structure and function of cholinesterases. In: Toxicology of organophosphate and carbamate compounds (Gupta R, ed), pp 161-186. Amsterdam: Elsevier.

Rosenberry TL, Scoggin DM (1984) Structure of human erythrocyte acetylcholinesterase. Characterization of intersubunit disulfide bonding and detergent interaction. J Biol Chem 259:5643-5652.

Rotundo RL, Carbonetto ST (1987) Neurons segregate clusters of membrane-bound acetylcholinesterase along their neurites. Proc Natl Acad Sci USA 84:2063-2067.

Rotundo RL, Rossi SG, Anglister L (1997) Transplantation of quail collagen-tailed acetylcholinesterase molecules onto the frog neuromuscular synapse. J Cell Biol 136:367-374. 
Simon S, Krejci E, Massoulie J (1998) A four-to-one association between peptide motifs: four C-terminal domains from cholinesterase assemble with one proline-rich attachment domain (PRAD) in the secretory pathway. EMBO J 17:6178-6187.

Soreq H, Zakut H (1990) Expression and in vivo amplification of the human acetylcholinesterase and butyrylcholinesterase genes. Prog Brain Res $84: 51-61$

Torres JC, Behrens MI, Inestrosa NC (1983) Neural 16S acetylcholinesterase is solubilized by heparin. Biochem J 215:201-204.

Wang GL, Moore ML, McMillin JB (2002) A region in the first exon/intron of rat carnitine palmitoyltransferase Ibeta is involved in enhancement of basal transcription. Biochem J 362:609-618.
Wilson MD, Riemer C, Martindale DW, Schnupf P, Boright AP, Cheung TL, Hardy DM, Schwartz S, Scherer SW, Tsui LC, Miller W, Koop BF (2001) Comparative analysis of the gene-dense ACHE/TFR2 region on human chromosome 7q22 with the orthologous region on mouse chromosome 5 . Nucleic Acids Res 29:1352-1365.

Xie W, Stribley JA, Chatonnet A, Wilder PJ, Rizzino A, McComb RD, Taylor P, Hinrichs SH, Lockridge O (2000) Postnatal developmental delay and supersensitivity to organophosphate in gene-targeted mice lacking acetylcholinesterase. J Pharmacol Exp Ther 293:896-902.

Xu X, Li C, Garrett-Beal L, Larson D, Wynshaw-Boris A, Deng CX (2001) Direct removal in the mouse of a floxed neo gene from a three-loxP conditional knockout allele by two novel approaches. Genesis 30:1-6. 